\title{
Growing of the containerized seedlings of english oak (Quercus robur L.) to establish sustainable plantations on wooded and reclaimed lands
}

\author{
Evgeny Romanov, Vitaly Krasnov, and Roman Segeev* \\ Volga State University of Technology, Forestry Department, 424000, 3, Lenin Square, Yoshkar-Ola, \\ Republic of Mari El, Russian Federation
}

\begin{abstract}
The topical issues for elaboration of new approaches to grow English oak seedlings with the purpose to establish sustainable plantations on wooded and reclaimed lands are considered in the article. The goal of the research is to elaborate a technology for growing the containerized seedlings of English oak. An integrated assessment of the variants of the experiment (growing of seedlings in Hiko and Plantek containers with various volumes of cells) was made by a number of factors: a) plant growth intensity; b) number of seedlings from a unit of area; c) stability of rootball; d) cultivation cost for a plant; e) establishment of plants in the first and second years of growth on a site. Then by G. F. Lakin method, a distribution series was composed where the place of each variant of the experiment (cell volume) was matched to the indicator value. Depending on the place in the distribution series, each variant was given a certain point. The sum of points for each cell volume was divided into maximum possible point (number of indices, multiplied by number of variants) and obtained a weighted average point of the influence of cell volume on the final growth index in a greenhouse and on a site. Based on the research results, a new way of acorn sowing in the containers was offered. It is recommended that the acorns to be planted in a container with a pointed end up and to be embedded at a depth of $1.0 \mathrm{~cm}$ from the top of the substrate. It makes it possible to form physiologically active roots of the second and third orders from the top to the bottom of the container cell, to enhance the stability of rootball.
\end{abstract}

\section{Introduction}

Depletion of natural resources is one of the most serious ecological problems for modern Russia and many other countries. This phenomenon is coming from the influence of various factors on the natural ecosystems (anthropogenic factor is included). Anthropogenic impact may have an exhausting influence on the biosphere and it sometimes makes the natural environment unsuitable for living. English oak performs a number of

\footnotetext{
${ }^{*}$ Corresponding author: sergeevphd@yandex.ru
} 
ecological functions, the main of them are soil-protective and climate-regulating functions. English oak is widely used for establishment of forest shelter belts, roadside plantations, and plantations near the ravines. It is also used for forestation of small flat-bottom valleys, riversides, and other reclaimed lands.

Oak forests play a significant role in the functioning of the biosphere. They produce and accumulate biomass, produce oxygen and regulate the composition of the atmosphere of the Planet and more. Meanwhile, the decline and reduction of the forests with the predominance of English oak (Quercus robur L.) is observed in Russia and across the globe. Such degradation can cause a number of ecological problems, related to the loss of gene bank of valuable plant populations, reduction in number and extinction of the entire species $[1,2,3,4,5,6]$. Conservation and regeneration of oak forests is a very important task for the government.

\section{Methods}

The acorns were collected in English oak (Quercus robur L.) plantations of Botanical Garden-Institute (Volga State University of Technology, Republic of Mari El). Acorns were processed with Baileton (fungicide). They were manually planted in the containers of two types: Hiko and Plantek (eight designs of both). Cell volumes of Hiko containers varied between 25 and $530 \mathrm{~cm}^{3}$, while cell volumes of Plantek containers were between 50 and $275 \mathrm{~cm}^{3}$. Performance specifications of containers are given in table 1 .

The experiment was laid in greenhouse conditions and repeated three times, every time no less than 50 seedlings were grown. Containers were manually filled with bog peat (№7) of "Veltorf" trade name brought from the Pskov Region (year of delivery - 2014). Containers were set on racks of $15 \mathrm{~cm}$ to ensure air trimming of the root system.

With a view to select the substrate for growing the containerized oak seedlings, nine kinds of substrates were considered: 1 - compost of sawdust and sewage sludge; 2 transitional peat produced at Paranga Peat Company (Republic of Mari El, year of production - 2015); 3 - substrate of sand, peat, and biocompost; 4 - transitional peat produced at Paranga Peat Company used for cultivation of planting material (coniferous species under coverage) for a period of three years; 5 - compost of cattle manure; 6 - bog peat brought from the Pskov Region (2013 ); 7 - bog peat brought from the Pskov Region (2014); 8 - transitional peat produced at Paranga Peat Company (year of production 2015) stored without housing for a period of three years; 9 - soil of oak forest. The content of organic matter in the substrate was determined with dry ashing technique (GOST 2671485, GOST 27980-88). Acidity ( $\mathrm{pH}$ salt extract) was measured with the use of the potentiometric method (GOST 27979-88). Active forms of potassium and highly soluble compounds of phosphates in extracts were determined by the method of A. T. Kirsanov (GOST 26207-91). Nitrate nitrogen was measured by the disulfophenolic method (GOST 26951-86). Basic characteristics of the substrates are given in table 2.

Table 1. Types and performance specifications of containers.

\begin{tabular}{|c|c|c|c|c|c|c|c|c|c|}
\hline $\begin{array}{l}\text { Seq } \\
\text { No. }\end{array}$ & $\begin{array}{c}\text { Hiko } \\
\text { containe } \\
\text { rs }\end{array}$ & $\begin{array}{c}\text { Size } \\
\text { of } \\
\text { casset } \\
\text { te, } \\
\text { mm }\end{array}$ & $\begin{array}{l}\text { Cell } \\
\text { volu } \\
\text { me, } \\
\mathrm{cm}^{3}\end{array}$ & $\begin{array}{l}\text { Num } \\
\text { ber of } \\
\text { cells } \\
\text { in a } \\
\text { casset } \\
\text { te, } \\
\text { pcs. }\end{array}$ & $\begin{array}{l}\text { Seq } \\
\text { No. }\end{array}$ & $\begin{array}{c}\text { Plantek } \\
\text { contain } \\
\text { ers }\end{array}$ & $\begin{array}{c}\text { Size } \\
\text { of } \\
\text { casset } \\
\text { te, } \\
\text { mm }\end{array}$ & $\begin{array}{l}\text { Cell } \\
\text { volu } \\
\text { me, } \\
\mathrm{cm}^{3}\end{array}$ & $\begin{array}{c}\text { Num } \\
\text { ber of } \\
\text { cells } \\
\text { in a } \\
\text { casset } \\
\text { te, } \\
\text { pcs. }\end{array}$ \\
\hline 1. & $\begin{array}{l}\text { Hiko } \\
\text { V-25 }\end{array}$ & $\begin{array}{l}352 \times \\
216 \times\end{array}$ & 25 & 128 & 1. & $\begin{array}{c}\text { Plantek } \\
121 \mathrm{~F}\end{array}$ & $\begin{array}{c}385 \times \\
385 \times\end{array}$ & 50 & 121 \\
\hline
\end{tabular}




\begin{tabular}{|c|c|c|c|c|c|c|c|c|c|}
\hline \multicolumn{5}{|c|}{85} & \multicolumn{5}{|c|}{73} \\
\hline 2. & $\begin{array}{c}\text { Hiko } \\
\text { V-50 } \\
\text { SideS1 } \\
\text { it }\end{array}$ & $\begin{array}{c}352 \times \\
216 \times \\
87\end{array}$ & 50 & 67 & 2. & $\begin{array}{c}\text { Plantek } \\
100 \mathrm{~F}\end{array}$ & $\begin{array}{c}385 \times \\
385 \times \\
90\end{array}$ & 81 & 100 \\
\hline 3. & $\begin{array}{l}\text { Hiko } \\
\text { V-90 } \\
\text { AirBl } \\
\text { ock } \\
\end{array}$ & $\begin{array}{c}352 \times \\
216 \times \\
92\end{array}$ & 90 & 40 & 3. & $\begin{array}{c}\text { Plantek } \\
63 \mathrm{~F}\end{array}$ & $\begin{array}{c}397 \times \\
294 \times \\
90\end{array}$ & 90 & 63 \\
\hline 4. & $\begin{array}{c}\text { Hiko } \\
\text { V-120 } \\
\text { SideSl } \\
\text { it }\end{array}$ & $\begin{array}{c}352 \times \\
216 \times \\
110\end{array}$ & 120 & 40 & 4. & $\begin{array}{c}\text { Plantek } \\
64 \mathrm{~F}\end{array}$ & $\begin{array}{c}385 \times \\
385 \times \\
73\end{array}$ & 115 & 64 \\
\hline 5. & $\begin{array}{c}\text { Hiko } \\
\text { V-150 } \\
\text { SideSl } \\
\text { it }\end{array}$ & $\begin{array}{c}352 \times \\
216 \times \\
100\end{array}$ & 150 & 24 & 5. & $\begin{array}{c}\text { Plantek } \\
64 \mathrm{FD}\end{array}$ & $\begin{array}{c}385 \times \\
385 \times \\
110\end{array}$ & 128 & 64 \\
\hline 6. & $\begin{array}{c}\text { Hiko } \\
\text { V-350 }\end{array}$ & $\begin{array}{c}352 \times \\
216 \times \\
125 \\
\end{array}$ & 350 & 15 & 6. & $\begin{array}{c}\text { Plantek } \\
49 \mathrm{~F}\end{array}$ & $\begin{array}{c}385 \times \\
385 \times \\
100\end{array}$ & 155 & 49 \\
\hline 7. & $\begin{array}{c}\text { Hiko } \\
\text { V-400 }\end{array}$ & $\begin{array}{c}352 \times \\
216 \times \\
150\end{array}$ & 400 & 15 & 7. & $\begin{array}{c}\text { Plantek } \\
36 \mathrm{~F}\end{array}$ & $\begin{array}{c}385 \times \\
385 \times \\
90\end{array}$ & 230 & 36 \\
\hline 8. & $\begin{array}{c}\text { Hiko } \\
\text { V-530 }\end{array}$ & $\begin{array}{c}352 \\
\times 216 \times \\
200\end{array}$ & 530 & 15 & 8. & $\begin{array}{c}\text { Plantek } \\
35 \mathrm{~F}\end{array}$ & $\begin{array}{c}400 \times \\
300 \times \\
130\end{array}$ & 275 & 35 \\
\hline
\end{tabular}

The integrity of rootball of a substrate when extracting a seedling out from a container was defined using the "arbitrary scale for damage tolerance" $(1-5): 1-100 \%$ root ball is broken down; $2-80 \%$ root ball is broken down; 3 - up to $60 \%$ root ball is broken down; 4 - up to $30 \%$ rootball is broken down; $5-100 \%$ rootball is kept. Germinating capacity of acorns was determined 30 days after sowing them in a greenhouse as a number of young seedlings to a number of sowed seeds, expressed as a percentage. Biometric data for seedlings were defined with the measurement tools: height was measured with a ruler with mm markings accurate within $0.001 \mathrm{~mm}$; root collar diameter - with a trammel accurate within $0.001 \mathrm{~mm}$. Oven-dry weight of seedlings after oven drying at a temperature of 105 ${ }^{\circ} \mathrm{C}$ was determined with an electronic weighing machine accurate within $0.01 \mathrm{~g}$. According to the Rules of Forest Restoration, the seedlings with the height of stipitate no less than 12 $\mathrm{cm}$ and root collar diameter of no less than $3 \mathrm{~mm}$ were considered to be the typical ones (Order of the Ministry of Natural Resources and Environment of the Russian Federation of 29.06.2016 № 375).

Table 2. Agrophysical and agrochemical characteristics of the substrates.

\begin{tabular}{ccccccccccc}
\hline № & $\begin{array}{c}\text { Characteristics of } \\
\text { the substrate }\end{array}$ & $\begin{array}{c}\text { № } \\
\mathbf{1}\end{array}$ & №2 & №3 & №4 & №5 & №6 & №7 & №8 & №9 \\
\hline 1. & $\begin{array}{c}\text { Share of organic } \\
\text { matter, \% }\end{array}$ & $\begin{array}{c}19 . \\
8\end{array}$ & 56.0 & 47.5 & 71.8 & 23.4 & 72.3 & 74.2 & 74.9 & 12.9 \\
\hline 2. & Bulk density, g/cm & $\begin{array}{c}0.9 \\
7\end{array}$ & 0.57 & 0.85 & 0.43 & 1.04 & 0.46 & 0.43 & 0.53 & 1.15 \\
\hline 3. & $\begin{array}{c}\text { Environment reaction } \\
(\mathrm{pH})\end{array}$ & $\begin{array}{c}4.2 \\
5\end{array}$ & 5.35 & 6.1 & 4.88 & 6.7 & 6.11 & 3.33 & 5.49 & 7.13 \\
\hline 4. & $\begin{array}{c}\text { Content of nitrate } \\
\text { nitrogen, } \mathrm{mg} / 100 \mathrm{~g}\end{array}$ & $\begin{array}{c}32 . \\
0\end{array}$ & 130.0 & 51.0 & 79.0 & 125.0 & 255.0 & 59.0 & 91.0 & 68.0 \\
\hline
\end{tabular}




\begin{tabular}{ccccccccccc}
\hline 5. & $\begin{array}{c}\text { Content of labile } \\
\text { phosphorus, } \mathrm{Mg} / 100 \mathrm{~g}\end{array}$ & $\begin{array}{c}18.6 \\
\text { 6 }\end{array}$ & 204.3 & 139.0 & 160.3 & 234.0 & 302.9 & 76.6 & 24.5 & 153.0 \\
\hline $\begin{array}{c}\text { Content of } \\
\text { exchangeable } \\
\text { potassium, } \mathrm{Mg} / 100 \mathrm{~g}\end{array}$ & $\begin{array}{c}42 . \\
5\end{array}$ & 215.2 & 99.7 & 194.2 & 335.9 & 708.4 & 167.9 & 26.2 & 103.9 \\
\hline
\end{tabular}

An integrated assessment of the variants of the experiment (growing of seedlings in Hiko and Plantek containers with various volumes of cells) was made by a number of factors: a) plant growth intensity; b) number of seedlings from a unit of area; c) stability of rootball; d) cultivation cost for a plant; e) establishment of plants in the first and second years of growth on a site. The difference between different variants of the experiment was significant (Fcalc.>Ftable.). By G.F. Lakin method [7], distribution series was composed where the place of each variant of the experiment (cell volume) was matched to the indicator value. Depending on the place in the distribution series, each variant was given a certain point. The highest point had number 1 in a row. The sum of points for each cell volume was divided into a maximum possible point (number of indices, multiplied by number of variants) and obtained a weighted average point of the influence of cell volume on the final growth index in a greenhouse and on a site. Some other indices depending on the volume of cells were also obtained. Field data processing was performed by the method of mathematical statistics through the use of Statistika 6 and Excel 2010.

\section{Results}

The Scandinavian technology should be taken as a basis for growing the containerized seedlings of English oak. The technology includes automation of all the activities with a view to intensify the process. However, it is obligatory to know the growth characteristics of the containerized seedlings of English oak as well as the development of root system in the limited volume of a cell to use the considered technology. It particularly concerns the sector for elaboration of a sowing device. For the experiment, the acorns were collected in the territory of Botanic Garden-Institute (Volga State University of Technology). Average weight of acorn was $5.7 \mathrm{~g}$., length $-29.5 \mathrm{~mm}$, width- $17.3 \mathrm{~mm}$. Germinating capacity of acorns was $70.3 \%$.

The experiments, conducted in the greenhouses of Botanic Garden-Institute (Volga State University of Technology), revealed the differences in the growth of root system and in the length of underground part of a stipitate of oak seedlings depending on the way of acorn distribution in a container (Table 3).

Table 3. Influence of the method of acorns seeding on the indices of English oak seedlings.

\begin{tabular}{llll}
\hline Variant of experiment & Stability of rootball, points & $\begin{array}{l}\text { Length of } \\
\text { underground } \\
\text { part } \\
\text { stipitate, cm }\end{array}$ & $\begin{array}{l}\text { Length of } \\
\text { of } \\
\text { oft } \\
\text { system, } \\
\text { cm }\end{array}$ \\
\hline Offered method of seeding & 4.7 & 1.3 & 9.4 \\
\hline Regular method of seeding & 4.1 & 3.1 & 7.5 \\
\hline Least significant difference 05 & 0.44 & 0.70 & 1.13 \\
\hline Fcalc. & $14.09^{*}$ & $49.11^{*}$ & $23.50^{*}$ \\
\hline Ftable. & 7.71 & 7.71 & 7.71 \\
\hline
\end{tabular}

* - considerableness of differences is proved at a $5 \%$ level of importance. 
Regular method of seeding supposes that an acorn to be planted with a pointed end down or chaotically which is of no high significance for sowing the acorns in the soil of a nursery or on a site. Seeding of the acorns in a container by said method is a different story. In this case, there is no uniform allocation of roots throughout the substrate. Hence, extracting the seedlings out from the container results in the loss of a top of the substrate. It happens due to the fact that a root collar is located lower the upper part of the container and the plant roots do not hold this part of the substrate (Figure 2a).

We developed a new method of acorn planting. This method makes it possible to solve the considered problem [29]. It is suggested that the acorns to be planted in a container with the pointed end up and to be embedded at a depth of $1.0 \mathrm{~cm}$ from the top of the container (Figure 2b). It makes it possible to form physiologically active roots of the second and third orders from the top to the bottom of the container, to enhance the stability of rootball, and to improve the establishment of plants after replanting them on a site.

The problem of the choice of the substrate, suitable for the use in the industrial production of the containerized seedlings of English oak, is of current importance. Scientific researches and experience of growing the seedlings of coniferous species under cover have shown that the content of mineral elements in the substrate was not the main aspect for its applicability. It is the physical properties of the substrate to be the main aspect for its applicability [30]. The experiment with nine substrates (most part of them is of local production (Republic of Mari El)) for growing the seedlings of English oak in Hiko containers (cell volume is $150 \mathrm{~cm}^{3}$ ) proves this statement. The correlation between the bulk density and growth of seedlings is direct negative $(\mathrm{r}=-0.74)$. The content of active forms of $\mathrm{P}_{2} \mathrm{O}_{5}, \mathrm{~K}_{2} \mathrm{O}$ and $\mathrm{NO}_{3}$ in the substrate has no great impact on the biometric indices of oneyear seedlings (Fcalc. $<$ Ftable.).

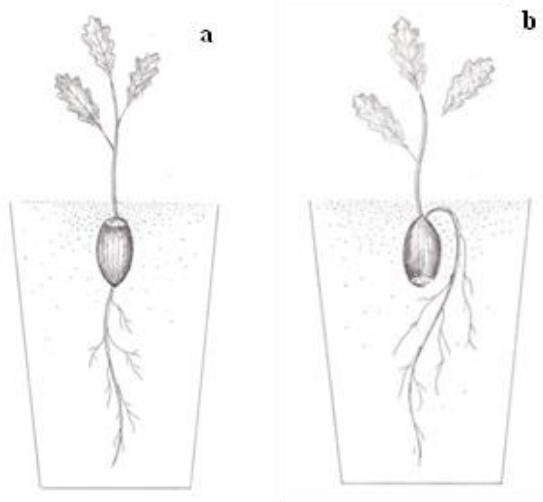

Fig 2. Regular (a) and offered (b) methods of a corn planting.

The seedlings of all the variants of the experiment have shown an average value for the height of stipitate and diameter of root collar. The height varies from $13 \mathrm{~cm}$ (see variant №6 - Veltorf of 2013) to 14.2 cm (№2 - peat of Paranga Peat Company of 2015); diameter of root collar varies from $5.8 \mathrm{~mm}$ (№2 - peat of Paranga Peat Company of 2015) to $7.1 \mathrm{~mm}$ (№7 - Veltorf of 2014). There are no conclusively established differences between different variants of peat and stability of rootball when extracting a seedling out from a container (Fcalc. $<$ Ftable.).

The core indicator of the substrate suitability for oak seedlings cultivation is a possibility to grow typical seedlings for one vegetation season (Figure 3 ). The maximum percentage of output of typical seedlings is observed at $0.43 \mathrm{~g} / \mathrm{cm}^{3}$ bulk density of the substrate. The seedlings grown in the containers with peat of the local peat company (№ 4 and № 8) had the highest output of typical seedlings. Thus, it is better to use the bog peat of 
local production (Republic of Mari El) and not to buy it in other Russian regions. Besides, the substrates on the basis of organic wastes can also be used to fill the containers in. Such substrates are composted and disinfected. Some positive results were also obtained with this kind of substrates. Use of the substrates on the basis of organic wastes will make it possible to involve a considerable volume of solid municipal and industrial wastes in economic turnover. Sod-podzolic sandy loam soil of oak forests showed minimum intensity of growth and $64 \%$ output of typical seedlings.

Maximum percentage of typical seedlings output is observed at $0.43 \mathrm{~g} / \mathrm{cm}^{3}$ bulk density of the substrate. The seedlings grown in the containers with peat of the local peat company (№ 4 and № 8) had the highest output of typical seedlings. Thus, it is better to use the bog peat of local production (Republic of Mari El) and not to buy it in other Russian regions. Besides, the substrate on the basis of organic wastes can also be used to fill the containers in. Such substrate is composted and disinfected. Some positive results were also obtained with this kind of substrate. Use of the substrate on the basis of organic wastes will make it possible to involve a considerable volumes of solid municipal and industrial wastes in economic turnover. Sod-podzolic sandy loam soil of oak forests showed minimum intensity of growth and $64 \%$ output of typical seedlings.

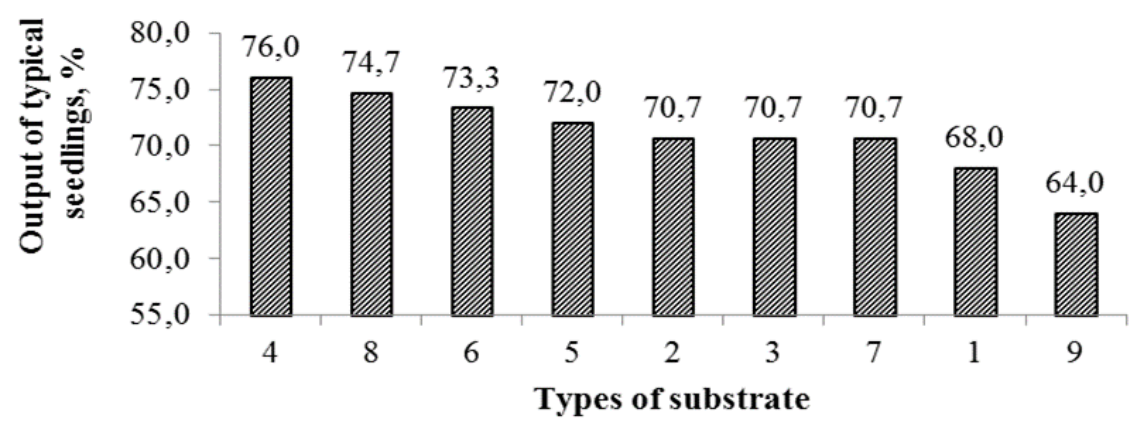

Fig 3. Output of typical seedlings of English oak for different types of substrate (1 - compost of sawdust and sewage sludge; 2 - transitional peat produced at Paranga Peat Company (Republic of Mari El, year of production - 2015); 3 - substrate of sand, peat, and biocompost; 4 - transitional peat produced at Paranga Peat Company (Republic of Mari El) used for cultivation of planting material (coniferous species under coverage) for a period of three years; 5 - compost of cattle manure; 6 - bog peat brought from the Pskov Region ( 2013 ); 7 - bog peat brought from the Pskov Region (2014 ); 8 - transitional peat produced at Paranga Peat Company (Republic of Mari El, year of production 2010) stored without housing for a period of three years; 9 - soil of oak forest).

Selection of the most suitable type of container to grow the containerized oak seedlings is one more important problem. On the one hand, we should go for the yield increase of typical seedlings from a unit of area. It is larger in the containers with minimum size of cells as the number of growing plants per square metre is higher (Figure 4). 

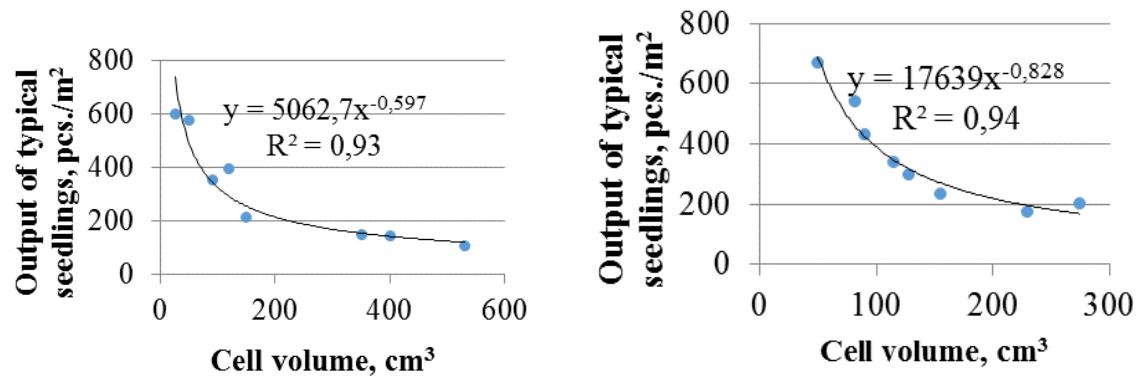

Fig 4. Output of typical seedlings of English oakper $1 \mathrm{~m}^{2}$ when growing the seedlings in $a$ - Hiko, $b-$ Plantek containers.

Otherwise, we should not forget about the quality of seedlings and their establishment in forest, which is ensured with an optimal area of plant nutrition and the volume of a container cell. Growing the planting material in the containers with large cells considerably increases its cost price in comparison with growing the plants in a small quantity of the substrate. Thus, it is necessary that the planting material to be estimated from a variety of angles (number of grown plants per unit of area, quality of plants, cost price for a plant, establishment and growth of plants on sites).

With the rank method, we made an integrated assessment of the variants of the experiment by combination of factors influencing the growth of oaks in a greenhouse and on sites, and having an impact on the economic efficiency for growing the seedlings (Figure $5)$.
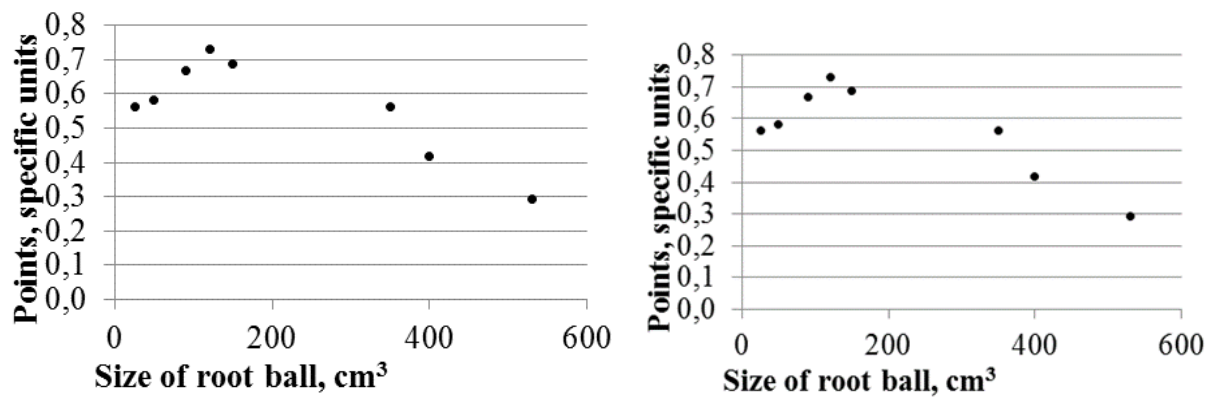

Fig 5. An integrated assessment for growing the seedlings of English oak in containers of various types and different cell volumes: $a$ - Hiko, $b$ - Plantek.

The seedlings grown in Hiko V-120 Sideslit containers with the cell volume of $120 \mathrm{~cm}^{3}$ have the highest point (0.7). The seedlings grown in Plantek $49 \mathrm{~F}$ containers also showed this figure $(0.7)$ but the cell volume was different $-155 \mathrm{~cm}^{3}$. Such containers are recommended to use for the industrial growing of the containerized seedlings of English oak.

\section{Discussion}

From 1961 to 2007, decrease of the area of oak groves in many regions of Russia is observed (Figure 2). 
Thus, over a period of 46 years the area of oak forests in the Republic of Bashkortostan has fallen by half. In other regions decrease of oak forests is also observed (Samara Region is the only exception).

In southern Russia, English Oak is widely used for protective afforestation as this species ensures implementation of many functions (field-protecting and erosion-preventing functions, control of land drainage, water evaporation, etc.). English oak is a droughtresistant and long life species. High trees with large crowns are of high ecological capacity,they keep the ideal wind penetration, and contribute to creation of kind microclimate [8]. For instance, the share of English oak in the forest belts of Kamennaya Steppe (Federal Nature Preserve in the Voronezh Region) is $61.5 \%$ [9]. However, the process of oak degradation is observed in these plantations (oak replacement by other species and lowering the ameliorative role of oaks by that).

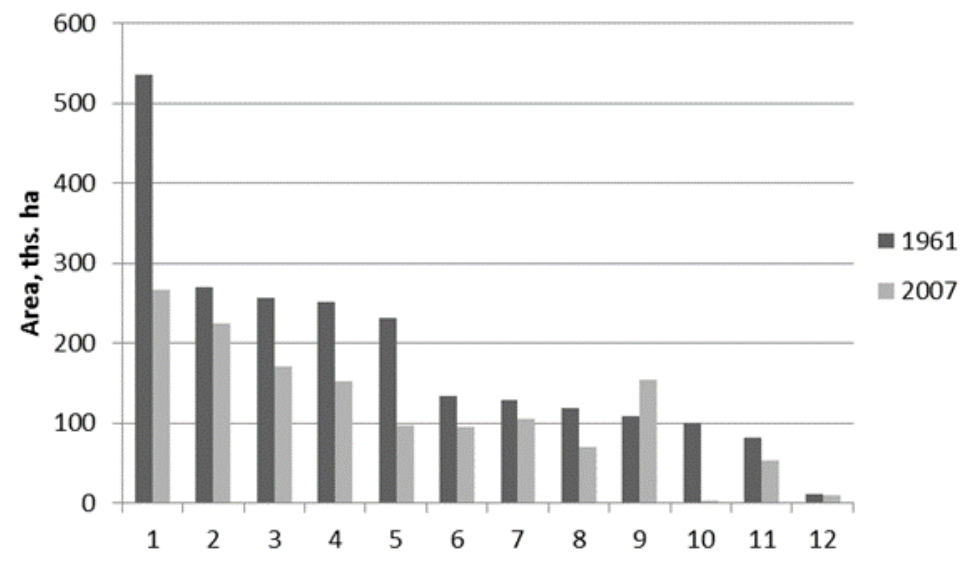

Fig 2. Change of Oak forests area in the Volga Federal District over the period 1961-2007 (1 Republic of Bashkortostan, 2 - Saratov Region, 3 - Republic of Tatarstan, 4 - Penza Region, 5 Ulyanovsk Region, 6 - Orenburg Region, 7 - Chuvash Republic, 8 - Republic of Mordovia, 9 Samara Region, 10 - Kirov Region, 11 - Nizhny Novgorod Region, 12 -Republic of Mari El).

The problem of oak groves regeneration is not a new one. It is explained with incomplete knowledge about oak particularities and lack of reliable technologies for its regeneration. We consider an inadequate attention to the introduction in practice plus selection, seedage, and growing of a high quality planting material to be major problems of poor artificial regeneration of English oak [10].

To save a valuable oak gene bank and to ensure the silvi cultural production with acorns, plus trees are selected and gene reserves are established. In the Middle Volga Region there are such pieces of oak forest in the Republic of Tatarstan and Chuvash Republic. In these regions, oak groves with valuable genetic properties were preserved. Stability against unfavourable factors of environment is considered to be the most important property for the forests. Such oak trees shall be conserved and propagated (microclonal propagation is included). The scientists of Russian Research Institute of Forest Genetics, Selection, and Biotechnology as well as the scientists of Volga State University of Technology perform the experiments for in vitro propagation.

The acorn harvest depends on the environmental factors, it is particularly sharp at the first stages of reproduction cycle. The periods of heavy bearing are interspersed with general lack of harvest (heavy bearing is observed every 5-7 years or even more rare - 1015 years) [10]. 
In order to conserve the valuable gene bank of oaks, it is obligatory to search for the new approaches. A number of experiments showed that the entire fetal rachides did not survive after cryogenic storage $[11,12,13-15,16-18]$. At that, many researches consider a heavy embryonic root to be a needless load, though it is more stable to drying. Today the researches continue to make the efforts to elaborate the new ways for a long term storage of valuable planting material.

There are some difficulties both for growing the planting material with the improved selective and genetic properties and for establishment and viability of oak after replanting it on a site. It is possible to escape the problems to a great extent when introducing the industrial technology of growing the containerized oak seedlings. The technology has the advantages in comparison with the bare root plants as it gives an opportunity to extend the term of planting, to achieve better establishment on a planting area, and to save the valuable seed material [19, 20, 21].

In the Scandinavian countries, growing of containerized seedlings (mainly coniferous species) is widely spread [22]. In the United States of America, some researchers work at the selection of containers and growing of seedlings of Spanish oak and cork oak [23, 24, 25]. In Russia, researchers of Saint Petersburg Forestry Research Institute, Russian Research Institute of Forest Genetics, Selection and Biotechnology, and Volga State University of Technology are engaged in the problem [19-21, 26-28].

\section{Conclusion}

Taking into consideration the periodicity of English oak (Quercus robur L.) fruiting, the necessity for conservation of its best genotypes, and for growing the planting material with the improved hereditary characters, industrial technology of growing the containerized seedlings is possible and perspective.

A way of acorn sowing in the containers has a significant impact on the growth of plants. Distribution of an acorn in a cell with a pointed end up makes it possible to form physiologically active roots of the second and third orders from a top of a container cell, to fix a rootball and to raise the survival ability of plants on sites (Patent № 2621993).

To grow the containerized seedlings of English oak, it is possible to use various types of substrates, including the substrate of solid municipal and agricultural wastes. The maximum output of typical seedlings was observed in the containers filled with the substrate of Paranga Peat Company (Republic of Mari El). Bulk density of the substrate is $0.43 \mathrm{~g} / \mathrm{cm}^{3}$. Forest soil is not useful for these purposes.

Use of Hiko and Plantek containers ensures growth of typical containerized seedlings of English oak under coverage of a nursery for one vegetation period. Despite the fact that the output of typical seedlings per unit of area is higher in the containers with minimum cell volume because of high density of plants spacing, such seedlings worse survive and grow in forest plantations as their aboveground part and root system are underdeveloped. Considering this, and an integrated assessment of a set of indicators, it is efficient to grow oak seedlings in Hiko V-120 Sideslit and Plantek 49 F containers with cell volumes of 120 and $155 \mathrm{~cm}^{3}$ accordingly.

To conserve and reproduce high yield and sustainable oak forests, it is desirable to restore forests using the containerized planting material with the improved selective and genetic properties grown according to the industrial technology. To elaborate and implement this technology, it is necessary: 1) to elaborate the modes of storage and preparation of acorns for planting, providing no less than $90 \%$ germinating capacity and maximum efficiency of utilization of containers; 2) to adapt the existing devices or elaborate principally new sowing machines for acorns planting in automatic mode, as implemented for growing the containerized seedlings of coniferous species; 3 ) to save and 
propagate the best genotypes of oak, resistant to deceases, anthropogenic burden, and unfavourable climatic factors, it is advisable to create a seed bank with an extended storage period and develop an effective technology for microclonal propagation in vitro.

The research was supported by the Ministry of Science and Higher Education of the Russian Federation (Grant № 075-15-2021-674) and Core Facility Centre «Ecology, biotechnologies and processes for obtaining environmentally friendly energy carriers» of Volga State University of Technology, Yoshkar-Ola.

\section{References}

1. V. A. Bugaev, A. L. Musievskiy, V. V. Tsaralunga, Forest J., 2 (2004)

2. V. A. Bugaev, A. L. Musievskiy, V. V. Tsaralunga, Dubravy lesostepi (Voronezh, Voronezh State University of Forestry and Technology named after G. F. Morozov, 2013)

3. V. G. Krasnov, V. F. Krasnova, I A. Alekseev, A. S. Yakovlev, Forest J., 6 (2007)

4. K. B. Lositskiy, Vosstanovlenie dubrav (Oak Groves Regeneration) (Moscow, Selkhozizdat, 1963)

5. V. V. Tsaralunga, Degradatsiya poroslevykh dubrav i ikh reabilitatsiya s pomoshchu sanitarnykh rubok (Decline of Oaks in Coppice Forests and Their Rehabilitation with Sanitary Clear Cuttings) (2005)

6. A. S. Yakovlev, I. A. Yakovlev, Dubravy Srednego Povolzhya (Oak Groves in the Middle Volga Region) (Yoshkar-Ola, MarGTU, 1999)

7. G. F. Lakin, Biometriya (Moscow, High School, 1990)

8. M. Yu. Sautkina, N. F. Kuznetsova, V. D. Tunyakin, Lesokhoz. Inform.: elektron. Setevoy J., 1 (2018)

9. A. G. Akhtyamov, V.V. Dokuchaev, Agricultural Res. Inst. Rep, 101 (2005)

10. S. A. Krukova, V. K. Shirnin, Lesotekhnicheskiy J., 2 (2016)

11. M. V. Ana, European J. of Forest Research, 131 (2012)

12. P. Berjak, N. W. Pammenter, L. Benech-Arnold, R. A. Sanchez, Handbook of seed physiology:applications to agriculture (New York-London-Oxford, The Haworth Press, 2004)

13. P. Chmielarz, M. Michalak, V. Pałucka, U Wasileńczyk, Plant Cell Repts, 30 (2011)

14. M. E. Gonzalez-Benito, R. B. Prieto, E. Herradon, C. Martin, Cryo Letters, 23 (2002)

15. H. M. Haggman, M. Rusanen, S. Jokippi, Plant cryopreservation: a practical guide (New York, 2008)

16. B. M. Reed, Plant cryopreservation: a practical guide (New York, 2008)

17. D. Touchell, C. Walters, Cryo Letters, 21 (2000)

18. C. Walters, N. W. Pammenter, P. Berjak, J. Crane, Seed Sci. Res., 11 (2001)

19. V. G. Krasnov, M. I. Smyshlyaeva, Influence of Planting Time on the Survival and Growth of the Containerized Seedlings of English Oak (Voronezh, Voronezh State University of Forestry and Technology named after G. F. Morozov, 2017)

20. E. M. Romanov, M. I. Smyshlyaeva, V. G. Krasnov, D. I. Mukhortov, Bull. of Volga State University of Technology, Ser.: Forest. Ecology. Nature Management, 3 (2017)

21. M. I. Smyshlyaeva, V. G. Krasnov (Voronezh, VGLU, 2015)

22. A. A. Birtseva, Proc. of Leningrad Forestry Res. Inst., 42 (1986) 
23. E. Chirino, A. Vilagrosa, E. I. Hernarndez, A. Matos, V. R. Vallejo, Forest Ecology and Management (2008)

24. M. Humphrey, B. A. Kleiss, H. M. Williams, WRP Technical note, 1 (1993)

25. J. McRae, USDA Forest Service Proceedings, 35 (2005)

26. A. A. Birtseva, I. M. Izvekova, Proc. of Leningrad Forestry Res. Inst., 45 (1988)

27. D. S. Burtsev, Proc. of Leningrad Forestry Res. Inst., 4 (2014)

28. O. M. Korchagin, P. M. Evlakov, L. A. Ryazantseva, V. Yu. Zapletin, Proceedings of III International scientific and practical conference (Saint-Petersburg, Saint-Petersburg Forestry Research Institute, 2013)

29. E. M. Romanov, V. G. Krasnov, D.I. Mukhortov, M. I. Smyshlyaeva, S. V. Kirillov, A. V. Antropova, Patent 2621993 RU C1, A 01 G 23/00 (2016)

30. E. M. Romanov, D. I. Mukhortov, A. V. Ushnurtsev, V. V. Uskova, FORESTRY, 2 (2009) 